\title{
Production and Evaluation of the Quality of Pearl Millet-based Fura (A Northern Nigerian Cereal-based Spiced Steamed Dough) as Affected by Bambara Groundnut Flour Supplementation
}

\author{
SALIHU Ibrahim ${ }^{1},{\text { KASUM Litini } \text { Afodia }^{1} \& \text { AGBARA Ikechukwu Gervase }}^{1^{*}}$ \\ ${ }^{I}$ Department of Food Science and Technology, University of Maiduguri, PMB 1069 Maiduguri Borno State, Nigeria. \\ Email: giagbara@ unimaid.edu.ng ${ }^{*}$ \& ORCID ID: https://orcid.org/0000-002-7994-5714*
}

DOI: http://doi.org/10.38177/ajast.2021.5302

Copyright: () 2021 SALIHU Ibrahim et al. This is an open access article distributed under the terms of the Creative Commons Attribution License, which permits unrestricted use, distribution, and reproduction in any medium, provided the original author and source are credited.

Pearl millet flour was substituted with Bambara groundnut flour (0-20\%) to form blends and used in fura preparation. Functional and microbiological profiles of the flours and food samples respectively as well as proximate and sensory properties were evaluated. Supplementation had raised the nutritional value of the foods. Swelling power and water absorption capacity had increased with an increase in the level of Bambara groundnut flour addition whereas bulk density and viscosity had decreased; the results were as follows-swelling power (23.616-24.203\%), water absorption capacity $(3.350-3.650 \mathrm{~g} / \mathrm{g})$, bulk density $(0.791-0.785 \mathrm{~g} / \mathrm{cm} 3)$, and viscosity $(52.965-50.210 \mathrm{mPa}-\mathrm{s})$. The moisture content, ash, fat, protein, fibre, carbohydrate and total energy level were found as follows- $42.730-45.500 \%, 0.510-0.850 \%, 3.275-7.95 \%, 3.750-9.375 \%, 0.775-0.900 \%, 35.425-48.960 \%$ and $240.315-250.750 \mathrm{kcal} / 100 \mathrm{~g}$ respectively. Concentration of anti-nutritional factors, alkaloids, flavonoids, phytic acids and tannins ranged from 0.09 to $0.15 \mathrm{~g} / 100 \mathrm{~g}, 0.28$ to $0.35 \mathrm{~g} / 100 \mathrm{~g}, 7.31$ to $9.83 \mathrm{~g} / 100 \mathrm{~g}$ and 0.04 to $0.16 \mathrm{~g} / 100 \mathrm{~g}$ respectively. The minerals contents were found to be significant as follows Ca (11.55 to $24.35 \mathrm{mg} / 100 \mathrm{~g}$ ), $\mathrm{Fe}$ (2.71 to $5.72 \mathrm{mg} / 100 \mathrm{~g}), \mathrm{Zn}$ (1.58 to $1.83 \mathrm{mg} / 100 \mathrm{~g}$ ), P (46.12 to $96.37 \mathrm{mg} / 100 \mathrm{~g}), \mathrm{Mg}(0.63 \mathrm{to} 0.77 \mathrm{mg} / 100 \mathrm{~g}$ ), $\mathrm{K}(36.19$ to $76.89 \mathrm{mg} / 100 \mathrm{~g}), \mathrm{Na}(4.08$ to $8.59 \mathrm{mg} / 100 \mathrm{~g})$. In- vitro protein digestibility at $1 \mathrm{~h}$ ranged between 72.67 to $75.43 \%$ and 73.95 to $79.13 \%$ a $6 \mathrm{hrs}$, starch digestibility ranged between 66.83 to $70.25 \%$. Microbial evaluation revealed moderate counts with the total microbial load of $1.23 \times 103 \mathrm{cfu} / \mathrm{g}$ (Table 5) in the food formulation F0MfB (100:00). Salmonella and Escherichia coli were not detected in fura food sample made from 80:20\% millet-bambara nut flour blend. Staphylococcus aureus, Staphylococcus epidemidis, Salmonella spp, Klebsiella spp, Pseudomonas and Escherichia coli were isolated with the following percentage of occurrences $32.28 \%, 25.00 \%, 3.48 \%, 16.46 \%, 19.62 \%$ and $3.16 \%$ respectively Sensory evaluation results revealed fura from $80: 20 \%$ millet-bambara nut flour blend had the best score, therefore the most preferred by the respondents.

Keywords: Pearl millet, Bambara groundnut, Supplementation, Fura, Digestibility, Microbial status.

\section{Introduction}

Fura is a local food of the Hausa/Fulani tribe and is most commonly in the whole of Northern Nigeria. Millet is a general term used for a wide range of cereals that describe several taxonomically divergent species of grass. Millet is thought to be among the first cultivated crops and has been a staple food ingredient in Central and Eastern Asia, Europe (mainly Russia), China, India, and some parts of Africa since ancient times [1]. It is an important food in many developing countries because of its ability to grow under adverse weather conditions such as limited rainfall. In addition, millet has many nutritious and medicinal properties [2]. Pearl millet is an important food for millions of people inhabiting the semi-arid tropics and is a major source of calories and vital component of food security in the semi-arid areas in the developing world [3]. The grain is processed in so many ways for preparation of various food products. Some of the products include, cooked whole grain, thin and thick porridges, steamed cooked grits (couscous, burabusko), Kunun zaki, Tuwo and Fura [4, 5, 6] Other traditionally processed pearl millet based foods in North-Eastern Nigeria include Yartsala, Shinkafan tudu (dehulled boiled millet), Fura, Gumba, Kunun tsamiya, Tuwo, and Nyauri etc. Enrichment of cereal-based food with other protein source has received considerable attention. Fura is solely a cereal-based food which will require the use of a grain legume as a supplement in order to complement the limiting nutrients in millet. Addition of Bambara nut will help to increase in quantity and quality of nutrients, and as well provide good quality essential amino acids in the supplemented fura because Bambara 
groundnut is a good source of protein high quality. It will also help to reduce the incidence of protein-energy malnutrition in people who consume this product as a staple. Bambara nut (Vigna subterranea (L.) Verdc.) is an African leguminous plant species, the cultivation of which predates that of groundnut.

Although occasionally grown in Asia and elsewhere, its cultivation is rare outside the African continent. The distribution of wild Bambara groundnut is also known to extend from Jos Plateau and Yola in Nigeria, to Garoua in Cameroon [7]. It is in West Africa that most of the world's Bambara groundnut is grown and where the crop is most prominent in the traditional cuisines of rural communities. Bambara nut plays a key role in the traditional food and culture of peoples in the North-Eastern part of Nigeria. Bambara nut is now widely distributed in the semi-arid zone of sub-Saharan Africa (SSA) and is the third most important food legume after cowpea (Vigna unguiculata) and groundnut [8].

Consumption of a single cereal may cause deficiency diseases because of the lower concentration of essential amino acids, minerals and vitamins. Therefore value addition for millet grains is another strategic approach followed to enhance nutritive value of these crops. Nutritive value and potential health benefits of millet grains were found comparable to major cereals such as wheat, rice, and maize though utilization of millet grain processing technologies such as fermentation, soaking/malting, and fortification/supplementation to improve the nutritional characteristics of millet grain is limited and is still mainly limited to populations in rural areas at the household level. This is due to lack of innovative millet processing technologies to provide easy-to-handle, ready-to-cook or ready-to-eat safe products and meals at a commercial scale that can be used to feed large populations in urban areas. Legumes are good sources of complex carbohydrates including fibre, both soluble and insoluble, legumes are a low-fat, high protein, source of vitamins, minerals and antioxidant, and highly satiating. It is important to note that multi grain blends are nutritionally superior to single grain flour [9]. Supplementing millet flour with Bambara nut flour which is a good source of fibre and low glycemic index levels would result to nutritionally enhanced composites flour which will be used for the production of nutritionally enhanced foods such as Fura.

Adu-Dapaah and Sangwan, [10] reported that Bambara nut seed is regarded as a complete food because it is rich in iron 4.9-48 mg/100g, compared to a range of 2.0-10.0 mg/100g for most food legumes, protein 18.0-24.0\% with high lysine and methionine contents, ash 3.0-5.0\%, fat 5.0-7.0\%, fibre 5.0-12.0\%, potassium 1144-1935 mg/100 g, sodium 2.9-12.0 mg/100 g, calcium 95.8-99 mg/ $100 \mathrm{~g}$, carbohydrate 51-70\%, oil 6-12\% and energy 367-414 $\mathrm{kcal} / 100 \mathrm{mg}$. Due to the high price of meat and fish, much importance is now placed on grain legumes as a source of protein in all the developing countries . Legumes are rich not only in proteins, but in other nutrients such as starch [11].

Fura is a semi-solid dumpling cereal based food used mostly together with the boiled milk sold by Fulani women in many cities of Northern Nigeria. It is produced mainly from pearl millet (Pennisetum glaucum) flour, blended with spices and made into balls and boiled. While still hot the cooked dough is pounded thoroughly in the mortar with the pestle (with addition of hot wter) until a smooth, slightly elastic and cohesive lump, fura is formed and later re-steamed. The aim of this study was to investigate the effect of Bambara nut flour inclusion on the quality and acceptability of fura, steamed dough consumed in Northern Nigeria. 


\subsection{Materials and methods}

\subsection{Collection of Materials}

Spices (cloves, ginger) , Bambara groundnut grains] for this research purchased at Wudil main market, Kano State Nigeria while Pearl millet grains (var SOSSAT C88) were obtained from Lake Chad Research Institute Maiduguri, Nigeria; materials were conveyed to Food Processing Laboratory of Kano State University of Science and Technology (KUST) Wudil for raw material preparation in the month of January, 2020.

\subsection{Processing of bambara groundnut}

The method of Nkama[12] was used for Bambara groundnut flour production with a slight modification as shown in Figure 1 below.

\subsection{Blend Formulation and Fura Preparation}

The Pearl millet (M) and Bambara groundnut (B) flours were blended in the ratios of 90:10 and 80:20, while 100\% Pearl millet served as the control. The blends were thoroughly blended in a kitchen mixer and used to prepare the fura using the traditional method as shown below.

Bambara groundnut (BG)

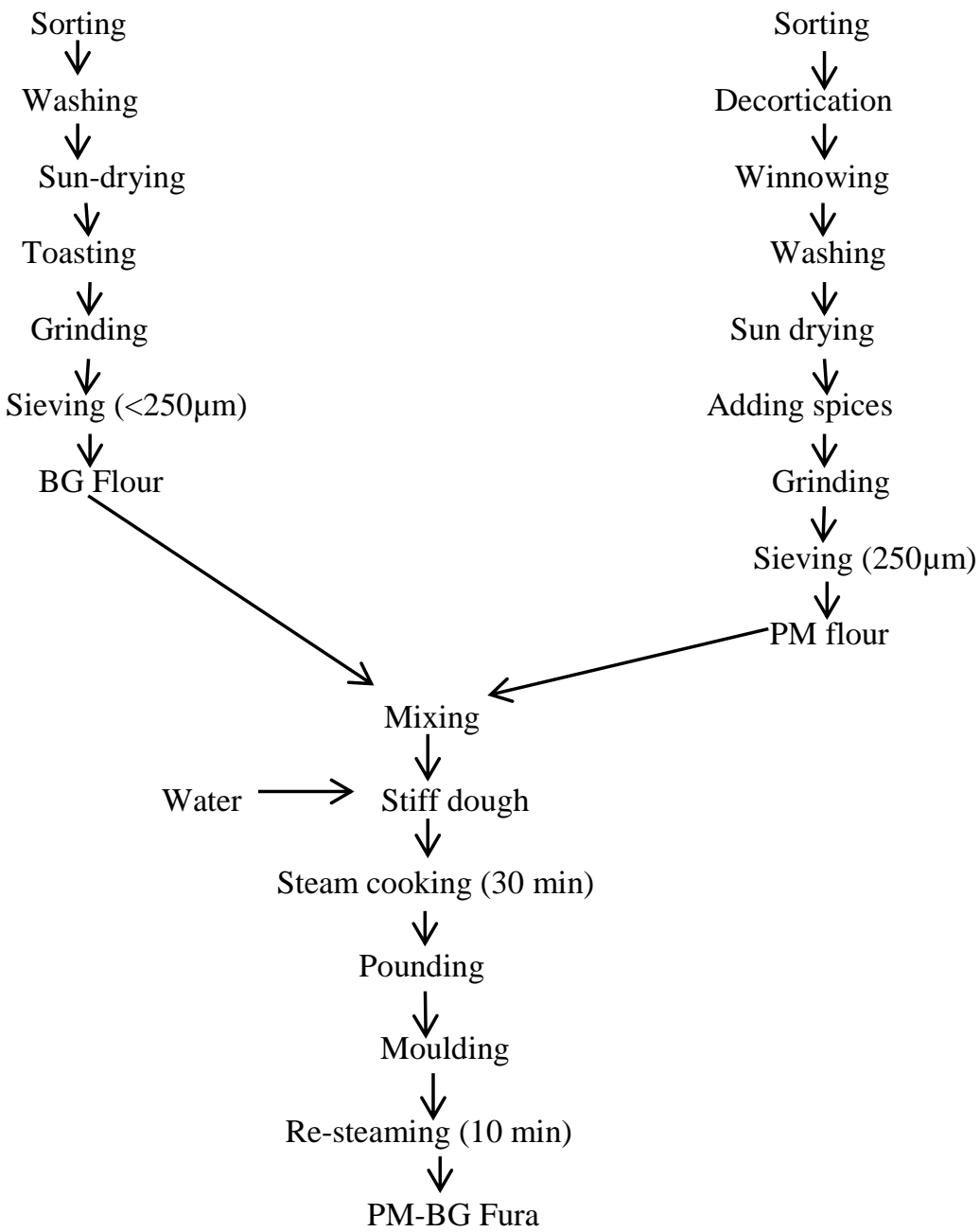

Fig.1. Flowchart for the production of PM-Fura 
Table 1. Formulation for Millet-Bambara Groundnut Fura (F) blends

\begin{tabular}{llll}
\hline Ingredients & $\mathbf{F}_{\mathbf{0}} \mathbf{M}_{\mathbf{f}}(\mathbf{1 0 0 : 0 0})$ & $\mathbf{F}_{\mathbf{1}} \mathbf{M}_{\mathbf{f}} \mathbf{B}(\mathbf{9 0 : 1 0})$ & $\mathbf{F}_{\mathbf{2}} \mathbf{M}_{\mathbf{f}} \mathbf{B}(\mathbf{8 0 : 2 0})$ \\
\hline Millet flour (\%) & 100 & 90 & 80 \\
Bambara nut flour (\%) & - & 10 & 20 \\
Cloves (g) & 0.6 & 0.6 & 0.6 \\
Ginger (g) & 1.5 & 1.5 & 1.5 \\
Water (ml) & 60 & 60 & 60 \\
\hline
\end{tabular}

$\mathbf{F}_{\mathbf{0}} \mathbf{M}_{\mathbf{f}}=100 \%$ millet flour, $\mathbf{F}_{\mathbf{1}} \mathbf{M}_{\mathbf{f}} \mathbf{B}=$ Millet flour (90\%) \& Bambara groundnut(10\%), $\mathbf{F}_{2} \mathbf{M}_{\mathbf{f}} \mathbf{B}=$ Millet flour (80\%) \& Bambara groundnut(20\%)

Three formulations of Fura blends were produced after using sound pearl millet grains, these were first cleaned to remove debris and sorted to remove unsound grains and other foreign matter, the grains were then de-hulled, and later washed, then sun-dried which reduced moisture content and spices added to improve nutrition and sensory property (Figure 1).

\section{Analysis}

\subsection{Functional Properties}

\section{Determination of water absorption capacity}

A gram (1g) of the sample was placed into graduated centrifuge tube and $10 \mathrm{ml}$ of distilled water was added and mixed thoroughly for 30 seconds. The sample was allowed to stand for 30 minutes at room temperature and then centrifuged at 5,000 rpm for 30 minutes. The volume of the free water was read directly from the graduated centrifuge tube. The water absorption capacity was expressed as grams of water absorbed per gram of sample [13].

\section{Determination of bulk density}

This was determined according to the method of Onwuka[13]. A 10ml capacity measuring cylinder was weighed. The cylinder was gently filled with the sample. The bottom of the cylinder was gently tapped on the laboratory bench several times until there was no further diminution of the sample level after filling to the $10 \mathrm{ml}$ mark.

\section{Determination of solubility and swelling power (Sp)}

This was determined according to the method of AOAC[14]. 1g of the sample was placed into a cleaned weighed graduated centrifuge tube and $40 \mathrm{ml}$ of distilled water added and mixed thoroughly. The mixture was placed on a water bath thermostatically controlled at $85{ }^{\circ} \mathrm{C}$ with continuous stirring for 30 minutes. The sample was allowed to cool to room temperature and then centrifuged at 2,200 rpm for 15 minutes. The supernatant was poured into a pre-weighed crucible and then placed in an oven to evaporate.

The solid residue in the crucible was weighed again and the difference in weight calculated as percentage solubility. The paste in the tube was then weighed and the swelling power (SP) determined by the following equation: 
$\% S p=\frac{\text { Weight of paste }}{\text { Weight of sample }} \times 100$

\section{Viscosity}

NDJ-5S Digital Rotary Viscometer equipped with set of spindles 1-4, beakers and samples. About 100ml of the flour suspension $(10 \% \mathrm{w} / \mathrm{v})$ for the different Fura flour blends was put in a glass beaker. The rotor protection bracket was mounted on the instrument, turning right for mounting and left for removing. The selected rotor was screwed into connecting bolt rod, taking care while slightly lifting the connecting rod when mounting or removing rotors. The rotor was put into the measured liquid till the level mark on the rotor reached the liquid surface. The samples were allowed to stand for two minutes under stable temperature before taking result. After putting on the machine the rotor was selected by pressing left and right while velocity was selected by pressing the down key. The return key was then pressed and the measurement started and finally the result was recorded when the data was within $10 \%-100 \%$ of the chosen scale ensuring the given precision, taking care of the appropriate unit, results expressed in milliPascal second (mPa-s) [14].

\subsection{Proximate composition of Raw materials, flour blends and Fura Samples}

For the determination of proximate composition of fura, raw material (millet, bambara groundnut nut and flour blends of raw materials were determined using procedures of AOAC [14]. Moisture content was determined by drying the sample at $105^{\circ} \mathrm{C}$ for about 3 hours. Ash content was determined by introducing the samples in the crucibles, using a pair of tongs into a muffle furnace at $500^{\circ} \mathrm{C}$ until fully ash. (Grey color ash). Protein content (\%N x 6.25) was determined by the Kjeldhal method. Crude fat was determined using the Soxhlet extraction with petroleum ether. Crude fibre was determined using 5 grams of the defatted sample involving alternate digestion with dilute acid and alkali and ashing. Carbohydrate was determined by 'difference'. Energy (E) values (Kcal) was determined according to the method described by Chinma and Gernah [15]. Energy values: $\{4 x($ protein $)+$ $4 x($ carbohydrate $)+9 x($ fat $)\}$.

\subsection{Microbial Analysis}

The total bacterial count, the serial dilution method as described by the American Public Health Association (APHA[16] was employed; $5 \mathrm{~g}$ of the sample was mixed with $225 \mathrm{ml}$ of $0.1 \%$ peptone water. The sample was shaken thoroughly to make a homogenate solution, this gave the dilution of $10^{-1} .1 \mathrm{ml}$ of this prepared solution was transferred to $9 \mathrm{ml}$ of the diluent $\left(0.1 \%\right.$ peptone water), this gave the dilution of $10^{-2}$. This procedure was repeated up to the fifth dilution which gave the dilution of $10^{-5}$.

Common bacterial pathogens associated with the foods are Escherichia coli- Eosin Methylene Blue (EMB), Pseudomonas aeruginosa- MacConkey (MA), Klebsiella spp- MacConkey (MA), salmonella spp-De-oxycitrate Agar (DCA), Staphylococcus epidermidis and Staphylococcus aureu- Mannitol Salt Agar (MSA). These organisms were isolated from the prepared foods and identified by colony morphology on selective media shown as paired with the organism. Gram-staining and standard biochemical tests were carried out for identification . Colonies were enumerated using digital colony counter and results expressed in colony forming unit per gram $(\mathrm{cfu} / \mathrm{g})$. 


\subsection{Sensory Evaluation}

The sensory evaluations of Fura samples were carried out by 20 respondents which comprised of students from the Department of Food Science and Technology, Kano University of Food Science and Technology (KUST) Wudil who are very familiar with the product, some of them are residents of the North-East sub region of Nigeria. The samples were ranked on a 9 point hedonic scale with 1 representing dislike extremely and 9 like extremely as described by [17]. The samples were prepared and served immediately after preparation. Individual samples were presented in a random pattern and judged based on attributes such as: aroma, texture, taste, appearance, and overall acceptability. A glass of clean water was given to the respondents to rinse their mouth in between each determination to avoid discrepancies in taste.

\subsection{Statistical analysis}

Determinations were done in duplicates except otherwise stated and the data generated were subjected to one-way analysis of variance $($ ANOVA) at $5 \%(\mathrm{p}<0.05)$ and the means separated using the Least Significance Difference (LSD) method [18]. The statistical analysis was carried out using MINI TAB version 17.

\section{Results and Discussion}

There was a significant variation $(\mathrm{p}<0.05)$ in the functional properties of the flours and blends (Table 2). The values of the functional properties generally decreased as pearl millet flour was substituted with bambara groundnut flour. Bulk density ranged from 0.779 to $0.791 \mathrm{~g} / \mathrm{cm}^{3}$, pearl millet flour had the highest bulk density and bambara groundnut whole grain flour, the least, the results were significantly different $(p<0.05)$ between all the flour samples. The decrease might be attributed to the lower density of bambara groundnut flour compared with millet flour. Plaami et al.,[19] reported that bulk density is influenced by the structure of the starch polymers and loose structure of the starch polymers could result in low bulk density. The results obtained in this study was higher when compared with the report of James et al. [20] (2018) who reported a bulk density range of 0.33 to $0.43 \mathrm{~g} / \mathrm{cm}^{3}$ for bambara groundnut-millet-based infant formula, and was also higher than the report of Adebayo-oyetoro et al[21]. on millet-based Fura powder supplemented with bambara nut. Bulk density is the measure of the heaviness of flour and is important in determining the packaging requirement and material handling [22]. Greater quantity of flour in a unit volume translate to greater nutritive value in terms of calorific value.

For the water absorption capacity (WAC), the results ranged from 3.300 to $4.650 \mathrm{~g} / \mathrm{g}$, bambara groundnut flour had the highest water absorption capacity and the least was in whole millet flour. WAC of fine millet and whole millet flours were not significantly different ( $p>0.05$ ) but were significantly different from the rest of the formulations. The high water absorption capacity might be attributed to the higher dry matter content of $\mathrm{B}_{\mathrm{f}}(100: 00)$.

The water absorption capacity in this study increased with an increase in the level of bambara groundnut flour inclusion (0-20\%) and this implies addition of bambara groundnut increased the water absorption capacity of the resulting blends which indicated that higher protein content was responsible for higher water absorption capacity (WAC) of bambara groundnut flour. Dietary fibres are known to have higher water holding capacity as seen in $\mathrm{B}_{\mathrm{f}}$ (100:00). Low water absorption capacity could be an advantage in storage stability as the rate of moisture 


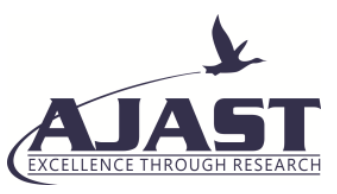

Asian Journal of Applied Science and Technology (AJAST)

Volume 5, Issue 3, Pages 13-31, July-September 2021

absorption could be relatively low hence reduced moisture availability for microbial growth and deleterious biochemical reactions. Proper mixing, consistency of fura requires higher water absorption of the blends which impact positively to the fura sensory attributes.

Swelling power values ranged from $23.512 \%$ in millet whole flour to $27.654 \%$ in bambara groundnut whole flour. There was no significant difference between results obtained for fine millet and whole grain flours. The swelling power results increased with an increase in the level of bambara groundnut inclusion in the pearl millet flour. The swelling power results agreed with the report by Agbara et al[22] on millet-bambara bean blends for yartsala production.

The viscosity of the flours ranged from $48.625 \mathrm{mPa}$-s in bambara groundnut flour, and was highest in millet whole grain flour with $56.555 \mathrm{mPa}$-s. The result in this study revealed that increasing the level of bambara groundnut inclusion marginally reduced the viscosity of the flours for the fura production because starch (millet flour) is a better thickener than protein (Bambara groundnut flour)

As observed from the results in Table 2, all the parameters determined were related to one another, the lower the bulk density with addition of bambara groundnut, the higher the flours ability to absorb water and the more the swelling power as well as the less the viscosity of the flours. Agbara et al.[23] similarly observed for blends of Yartsala production.

Table 2. Functional properties of the Millet- Bambara groundnut blends for Fura preparation

\begin{tabular}{ccccc}
\hline Sample code & $\begin{array}{c}\text { Bulk density } \\
\left(\mathbf{g} / \mathbf{c m}^{3}\right)\end{array}$ & $\begin{array}{c}\text { Water } \\
\text { absorption } \\
(\mathbf{g} / \mathbf{g})\end{array}$ & $\begin{array}{c}\text { Swelling power } \\
(\%)\end{array}$ & $\begin{array}{c}\text { Viscosity } \\
(\mathbf{m P a} / \mathbf{s})\end{array}$ \\
\hline $\mathrm{M}_{\mathrm{f}}(100: 00)$ & $0.791 \pm 0.000^{\mathrm{a}}$ & $3.350 \pm 0.071^{\mathrm{e}}$ & $23.616 \pm 0.187^{\mathrm{c}}$ & $52.965 \pm 0.290^{\mathrm{b}}$ \\
$\mathrm{M}_{\mathrm{wf}}(100: 00)$ & $0.787 \pm 0.000^{\mathrm{b}}$ & $3.300 \pm 0.000^{\mathrm{e}}$ & $23.512 \pm 0.021^{\mathrm{c}}$ & $56.555 \pm 0.629^{\mathrm{a}}$ \\
$\mathrm{B}_{\mathrm{f}}(100: 00)$ & $0.782 \pm 0.000^{\mathrm{d}}$ & $4.650 \pm 0.071^{\mathrm{a}}$ & $27.589 \pm 0.713^{\mathrm{a}}$ & $48.625 \pm 0.884^{\mathrm{d}}$ \\
$\mathrm{B}_{\mathrm{wf}}(100: 00)$ & $0.779 \pm 0.001^{\mathrm{e}}$ & $4.450 \pm 0.071^{\mathrm{b}}$ & $27.654 \pm 0.066^{\mathrm{a}}$ & $50.175 \pm 0.050^{\mathrm{c}}$ \\
$\mathrm{M}_{\mathrm{f}} \mathrm{B}_{\mathrm{f}}(90: 10)$ & $0.787 \pm 0.000^{\mathrm{b}}$ & $3.500 \pm 0.000^{\mathrm{d}}$ & $23.783 \pm 0.033^{\mathrm{bc}}$ & $51.315 \pm 0.205^{\mathrm{c}}$ \\
$\mathrm{M}_{\mathrm{f}} \mathrm{B}_{\mathrm{f}}(80: 20)$ & $0.785 \pm 0.000^{\mathrm{c}}$ & $3.650 \pm 0.071^{\mathrm{c}}$ & $24.203 \pm 0.301^{\mathrm{b}}$ & $50.210 \pm 0.028^{\mathrm{c}}$ \\
& & & &
\end{tabular}

Values are mean\#SD of duplicate determinations; means in a column bearing different supercipts are significantly different(p<.05). $M_{\mathrm{f}}=$ Fine millet flour $\mathrm{B}_{\mathrm{f}}=$ Bambara groundnut fineflour. $\mathrm{M}_{\mathrm{wf}}=$ whole millet flour $\mathrm{B}_{\mathrm{wf}}=$ Bambara groundnut whole flour.

Table 3 shows the proximate composition of millet and bambara groundnut whole grain, the raw material flours and the blends used for the preparation of millet-bambara groundnut fura production. Ash, protein and crude fibre contents increased as the level of Bambara groundnut flour increased (0-20\%). This redefines the true state of 
legume grains being good sources of protein, fat, ash and crude fibre than the cereals [24]. Bambara groundnut has been reported by several authors as being a complete food. The results obtained in this study were found to be higher than the report by Olaleye et al [25] regarding the chemical composition of bambara groundnut (2.46-4.36\%, 15.2-22.2\%, 2.47-6.99\% and 51.66-61.9\% for ash, protein, fat and carbohydrate respectively). The high content of ash, protein and fibre are important because protein is an important nutrient that plays a role in human metabolism, the fibre which indicates the indigestible cellulose was higher in Bambara groundnut. Also fibre is needed for bowel health and play vital role in metabolism of glucose and fat for healthy adults, $38 \mathrm{~g}$ for men and $25 \mathrm{~g}$ for women are recommended, 30 and $21 \mathrm{~g}$ are recommended for adults over the age of 50 [26]. The moisture, ash, fat, protein, crude fibre and carbohydrate contents of different samples of the processed fura are shown in Table $\mathbf{4}$ as follows: $42.73-45.50 \%, 0.51-0.85 \%, 3.275-7.95 \%, 0.78-0.90 \%$ and $35.425-48.96 \%$ respectively. There was a general increase in all the parameters determined other than carbohydrate which decreased as millet flour was increasingly substituted with bambara groundnut flour, the trend for the increase in ash, fat, protein and crude fibre level was expected as bambara groundnut was reported to contain high level of ash, protein and crude fibre [27] High moisture content levels in the food samples might be due to nature of fura processing such as double steaming coupled with the high water absorption capacity of the bambara groundnut flour. This high moisture level indicates higher chance of exposure to attack by micro-organisms therefore its storage potential might be low.

Table 3. Proximate composition (\%) of the Millet, Bambara groundnut flours and the blends

\begin{tabular}{llllllll}
\hline Sample code & Moisture & Ash & Fat & Protein & Crude fibre & Carbohydrate & Energy (Kcal) \\
\hline $\mathrm{M}_{\mathrm{f}}(100: 00)$ & $12.120 \pm 0.057^{\mathrm{b}}$ & $1.090 \pm 0.071^{\mathrm{e}}$ & $5.800 \pm 0.354^{\mathrm{d}}$ & $11.880 \pm 0.000^{\mathrm{c}}$ & $1.060 \pm 0.071^{\mathrm{d}}$ & $68.055 \pm 0.438^{\mathrm{a}}$ & $371.920 \pm 1.43^{\mathrm{d}}$ \\
$\mathrm{M}_{\mathrm{wf}}(100: 00)$ & $13.140 \pm 0.099^{\mathrm{a}}$ & $1.250 \pm 0.014^{\mathrm{de}}$ & $4.350 \pm 0.071^{\mathrm{e}}$ & $11.407 \pm 0.663^{\mathrm{c}}$ & $1.225 \pm 035^{\mathrm{bc}}$ & $68.629 \pm 0.599^{\mathrm{a}}$ & $359.290 \pm 0.382^{\mathrm{e}}$ \\
$\mathrm{B}_{\mathrm{f}}(100: 00)$ & $7.610 \pm 0.099^{\mathrm{d}}$ & $3.090 \pm 0.127^{\mathrm{b}}$ & $11.725 \pm 0.247^{\mathrm{a}}$ & $15.314 \pm 0.001^{\mathrm{a}}$ & $1.310 \pm 0.014^{\mathrm{b}}$ & $60.951 \pm 0.461^{\mathrm{c}}$ & $409.370 \pm 2.11^{\mathrm{a}}$ \\
$\mathrm{B}_{\mathrm{wf}}(100: 00)$ & $6.630 \pm 0.806^{\mathrm{e}}$ & $4.400 \pm 0.057^{\mathrm{a}}$ & $9.550 \pm 0.212^{\mathrm{b}}$ & $16.410 \pm 0.000^{\mathrm{a}}$ & $1.460 \pm 0.028^{\mathrm{a}}$ & $61.554 \pm 0.622^{\mathrm{c}}$ & $397.790 \pm 4.40^{\mathrm{b}}$ \\
$\mathrm{M}_{\mathrm{f}} \mathrm{B}(90: 10)$ & $10.210 \pm 0.042^{\mathrm{c}}$ & $1.300 \pm 0.028^{\mathrm{d}}$ & $6.900 \pm 0.141^{\mathrm{c}}$ & $12.500 \pm 0.884^{\mathrm{bc}}$ & $1.135 \pm 0.021^{\mathrm{cd}}$ & $67.955 \pm 0.778^{\mathrm{ab}}$ & $383.920 \pm 0.849^{\mathrm{c}}$ \\
$\mathrm{M}_{\mathrm{f}} \mathrm{B}(80: 20)$ & $9.620 \pm 0.085^{\mathrm{c}}$ & $1.640 \pm 0.028^{\mathrm{c}}$ & $7.350 \pm 0.071^{\mathrm{c}}$ & $13.688 \pm 0.795^{\mathrm{b}}$ & $1.205 \pm 0.078^{\mathrm{bc}}$ & $66.498 \pm 0.746^{\mathrm{b}}$ & $386.890 \pm 0.438^{\mathrm{c}}$
\end{tabular}

$\mathrm{M}_{\mathrm{f}}=$ Fine millet flour $\mathrm{B}_{\mathrm{f}}=$ Bambara groundnut flour $\mathrm{M}_{\mathrm{wf}}=$ whole millet flour $\mathrm{B}_{\mathrm{wf}}=$ Bambara groundnut whole flour. Mean values in the column bearing the identical superscripts are significantly not different $(\mathrm{P}>0.05)$

Table 4. Proximate Composition (\%) of Fura Supplemented with Bambara Groundnut Flour and the Control

\begin{tabular}{cccccccc}
\hline Sample & Moisture & Ash & Fat & Protein & Crude fibre & Carbohydrate & Energy (Kcal) \\
\hline $\mathrm{F}_{0} \mathrm{M}_{\mathrm{f}}(100: 00)$ & $42.730 \pm 0.099^{\mathrm{c}}$ & $0.510 \pm 0.014^{\mathrm{b}}$ & $3.275 \pm 0.177^{\mathrm{c}}$ & $3.750 \pm 0.000^{\mathrm{c}}$ & $0.775 \pm 0.106^{\mathrm{a}}$ & $48.960 \pm 0.198^{\mathrm{a}}$ & $240.315 \pm 0.799^{\mathrm{b}}$ \\
& & & & & & & \\
$\mathrm{F}_{1} \mathrm{M}_{\mathrm{f}} \mathrm{B}(90: 10)$ & $43.640 \pm 0.170^{\mathrm{b}}$ & $0.550 \pm 0.071^{\mathrm{b}}$ & $4.600 \pm 0.283^{\mathrm{b}}$ & $6.016 \pm 0.774^{\mathrm{b}}$ & $0.825 \pm 0.035^{\mathrm{a}}$ & $44.369 \pm 0.767^{\mathrm{b}}$ & $242.940 \pm 2.520^{\mathrm{b}}$ \\
$\mathrm{F}_{2} \mathrm{M}_{\mathrm{f}} \mathrm{B}(80: 20)$ & $45.500 \pm 0.170^{\mathrm{a}}$ & $0.850 \pm 0.042^{\mathrm{a}}$ & $7.950 \pm 0.071^{\mathrm{a}}$ & $9.375 \pm 0.884^{\mathrm{a}}$ & $0.900 \pm 0.000^{\mathrm{a}}$ & $35.425 \pm 1.082^{\mathrm{c}}$ & $250.750 \pm 0.156^{\mathrm{a}}$
\end{tabular}

$\mathrm{F}=$ Fura Subscripts 1 and 2 denote Bambara groundnut flour levels $10 \% \& 20 \%$, Fo represents the control, $\mathrm{M}_{\mathrm{f}}=$ Millet flour, $\mathrm{B}_{\mathrm{f}}=\mathrm{Bambara}$ groundnut flour. Mean values in the column bearing the identical superscripts are significantly not different $(\mathrm{P}>0.05)$ of duplicate determinations. 


\section{Mineral Contents of the Flours and Blends}

The mineral contents of the fura flour and the blends are presented in Table 5a. All the elements $(\mathrm{Mg}, \mathrm{K}$, and Na) other than $\mathrm{Ca}$ and $\mathrm{Fe}$ were found to have decreased in concentration in the raw material flour blends. The variations were significant as follows, $\mathrm{Ca}(17.80$ to $23.00 \mathrm{mg} / 100 \mathrm{~g}$ ), $\mathrm{Mg}$ (220.25 to $379.00 \mathrm{mg} / 100 \mathrm{~g}$ ), $\mathrm{Fe}$ ( 7.65 to 17.00 $\mathrm{mg} / 100 \mathrm{~g})$, $\mathrm{Na}(21.45$ to $38.25 \mathrm{mg} / 100 \mathrm{~g})$. The highest concentrations of $\mathrm{Ca}, \mathrm{Fe}$, were in the flour blends $\mathrm{M}_{\mathrm{f}} \mathrm{B}(80: 20)$, and that of $\mathrm{Mg}, \mathrm{K}$ and $\mathrm{Na}$ have been found to be highest in $\mathrm{M}_{\mathrm{f}}(100: 00)$. The high content of $\mathrm{Ca}$ and $\mathrm{Fe}$ in $\mathrm{B}_{\mathrm{f}}(100: 00)$ might be attributed to the grain's own composition, being a calcium rich grain, Amarteifio et al.,[28] reported that Ca levels ranged from 95.8 to $99.0 \mathrm{mg} / 100 \mathrm{~g}$. Fe result was higher than the report of Léder [29](2004) who reported Fe content of Pearl millet as $7.49 \mathrm{mg} / 100 \mathrm{~g}$ and the report of Kulthe et al [30] on millet cultivars who reported iron $(\mathrm{Fe})$ content in millets $(2.08$ to $8.12 \mathrm{mg} / 100 \mathrm{~g})$. Ca and $\mathrm{P}$ are very important in bones and teeth formation, growth, blood clothing, heart function and cell metabolism [31, 32]. Inadequate Ca intake results in rickets and risk of osteoporosis as well as hypertension and stroke. Fe values were found higher in this study than earlier reported. $\mathrm{Fe}$ is required for oxygen carrying capacity of haemoglobin and myglobin and as a co-factor for several enzymes (NHS Direct online [33]. Deficiency in Fe may lead to anaemia. Ca and Fe levels increased with an increase in the levels of bambara groundnut inclusion.

The high content of $\mathrm{Mg}, \mathrm{K}$ and $\mathrm{Na}$ could be linked to the high contents of these minerals in millets. $\mathrm{Ca}$ and $\mathrm{Mg}$ both plays important role in bone structure, muscles contraction, nerve impulse contraction, blood clothing, cell signaling [34]. Mg has been linked to meeting lower risk of type 2 diabetes. Potassium (K) is important in nerves and muscles function, it helps to offset some of the sodium harmful effects on blood pressure. Sodium is added to foods to maintain water balance in cells and its results were in agreement with the report of Nkama, and Malleshi[35] that reported Na contents of millet flour as 1596ppm $(159.6 \mathrm{mg} / 100 \mathrm{~g})$ and the report of Hillrocks $e t$ al. [36] on bambara groundnut utilization.

Table 5a: Mineral Contents of the Flours and Blends for Fura Production (mg/100g)

\begin{tabular}{llllll}
\hline Sample code & $\mathrm{Ca}$ & $\mathrm{Mg}$ & $\mathrm{Fe}$ & $\mathrm{K}$ & $\mathrm{Na}$ \\
\hline $\mathrm{M}_{\mathrm{f}}(100: 00)$ & $17.80 \pm 0.28^{\mathrm{d}}$ & $271.75 \pm 0.07^{\mathrm{b}}$ & $7.65 \pm 0.00^{\mathrm{d}}$ & $178.85 \pm 0.07^{\mathrm{a}}$ & $38.25 \pm 0.21^{\mathrm{a}}$ \\
$\mathrm{B}_{\mathrm{f}}(100: 00)$ & $22.30 \pm 0.14^{\mathrm{b}}$ & $379.00 \pm 0.14^{\mathrm{a}}$ & $11.00 \pm 0.14^{\mathrm{c}}$ & $86.75 \pm 0.21^{\mathrm{d}}$ & $29.35 \pm 0.21^{\mathrm{b}}$ \\
$\mathrm{M}_{\mathrm{f}} \mathrm{B}(90: 10)$ & $18.50 \pm 0.00^{\mathrm{c}}$ & $263.45 \pm 0.07^{\mathrm{c}}$ & $15.05 \pm 0.07^{\mathrm{b}}$ & $140.30 \pm 0.14^{\mathrm{b}}$ & $28.70 \pm 0.14^{\mathrm{c}}$ \\
$\mathrm{M}_{\mathrm{f}} \mathrm{B}(80: 20)$ & $23.00 \pm 0.14^{\mathrm{a}}$ & $220.25 \pm 0.21^{\mathrm{d}}$ & $17.00 \pm 0.00^{\mathrm{a}}$ & $123.15 \pm 0.21^{\mathrm{c}}$ & $21.45 \pm 0.21^{\mathrm{d}}$ \\
\hline
\end{tabular}

$\mathrm{M}_{\mathrm{f}}=$ Fine millet flour $\mathrm{B}_{\mathrm{f}}=$ Bambara groundnut flour

Mean values in the column bearing the identical superscripts are significantly not different $(\mathrm{P}>0.05)$

Mineral Contents of Bambara Groundnut Supplemented Pearl Millet-Based Fura and Control

Mineral contents of bambara groundnut supplemented pearl millet-based Fura and control are presented in Table $\mathbf{5 b}$, all the elements ( $\mathrm{Ca}, \mathrm{Fe}, \mathrm{Zn}$ and $\mathrm{P})$ analyzed were found to have increased in the Fura products with bambara 
groundnut flour supplementation. The variations were found to be significant as follows Ca (11.55 to 24.35 $\mathrm{mg} / 100 \mathrm{~g}$ ), Fe (2.71 to $5.72 \mathrm{mg} / 100 \mathrm{~g}$ ), Zn (1.58 to $1.83 \mathrm{mg} / 100 \mathrm{~g}$ ), P (46.12 to $96.37 \mathrm{mg} / 100 \mathrm{~g}$ ) whereas $\mathrm{Na}, \mathrm{K}$ and $\mathrm{Mg}$ were found to have decreased in concentration as bambara groundnut was added, $\mathrm{Mg}$ ( 0.63 to $0.77 \mathrm{mg} / 100 \mathrm{~g}), \mathrm{K}$ (36.19 to $76.89 \mathrm{mg} / 100 \mathrm{~g}$ ), $\mathrm{Na}(4.08$ to $8.59 \mathrm{mg} / 100 \mathrm{~g}$ ), this was attributed to millet grain being a good source of these minerals over bambara groundnut grain. Millet flour was reported to contain more K levels than bambara groundnut. $\mathrm{K}$ was reported to be in the range of 11.44 to $19.35 \mathrm{mg} / 100 \mathrm{~g}$ [28, 37]. Potassium (K) is important in nerves and muscles function, it helps to offset some of the sodium harmful effects on blood pressure. The high $\mathrm{Mg}$ content might be linked to higher $\mathrm{Mg}$ in foods made from millet than in bambara groundnut. Ayo and Aba[38] reported that millet based Madidi decreased in Mg content as more bambara groundnut was added. Magnesium is important for healthy bone. Higher intake of magnesium results in higher bone mineral density which is important in reducing the risk of bone fractures and osteoporosis. Olaleye et al. [25]) to range between 11.2 to $40.2 \mathrm{mg} / 100 \mathrm{~g}$ higher than the concentration of zinc in pearl millet that is $46.9 \mathrm{ppm}$ equivalent to $4.69 \mathrm{mg} / 100 \mathrm{~g}$ as reported by Nkama, and Malleshi [35] on Masa production. This might be the reason for the increased zinc content within the foods as Bambara groundnut was added. Zinc is important for the body's defense/immune system and is important in the synthesis, storage and secretion of insulin [39].

Table 5b. Mineral Contents of Bambara Groundnut Supplemented Pearl Millet-Based Fura and Control (mg/100g)

\begin{tabular}{cccccccc}
\hline Sample code & $\mathbf{C a}$ & $\mathbf{F e}$ & $\mathbf{N a}$ & $\mathbf{K}$ & $\mathbf{Z n}$ & $\mathbf{M g}$ & $\mathbf{P}$ \\
\hline $\mathrm{F}_{0} \mathrm{M}_{\mathrm{f}}(100: 00)$ & $11.55 \pm 2.36^{\mathrm{c}}$ & $2.71 \pm 0.55^{\mathrm{c}}$ & $8.59 \pm 0.83^{\mathrm{a}}$ & $76.89 \pm 4.56^{\mathrm{a}}$ & $1.58 \pm 0.03^{\mathrm{c}}$ & $0.77 \pm 0.04^{\mathrm{a}}$ & $46.12 \pm 4.30^{\mathrm{c}}$ \\
& & & & & & \\
$\mathrm{F}_{1} \mathrm{M}_{\mathrm{f}} \mathrm{B}(90: 10)$ & $20.18 \pm 2.36^{\mathrm{b}}$ & $4.74 \pm 0.55^{\mathrm{b}}$ & $8.04 \pm 0.24^{\mathrm{a}}$ & $60.88 \pm 7.39^{\mathrm{b}}$ & $1.70 \pm 0.16^{\mathrm{ac}}$ & $0.68 \pm 0.10^{\mathrm{b}}$ & $77.05 \pm 2.88^{\mathrm{b}}$ \\
$\mathrm{F}_{2} \mathrm{M}_{\mathrm{f}} \mathrm{B}(80: 20)$ & $24.35 \pm 2.36^{\mathrm{a}}$ & $5.72 \pm 0.55^{\mathrm{a}}$ & $4.08 \pm 0.83^{\mathrm{b}}$ & $36.19 \pm 4.16^{\mathrm{c}}$ & $1.83 \pm 0.08^{\mathrm{a}}$ & $0.63 \pm 0.07^{\mathrm{b}}$ & $96.37 \pm 10.18^{\mathrm{a}}$
\end{tabular}

$\mathrm{F}=$ Fura Subscripts 1 and 2 denote Bambara groundnut flour levels $10 \% \& 20 \%$, Fo represents the control, $\mathrm{M}_{\mathrm{f}}=$ Millet flour, $\mathrm{B}_{\mathrm{f}}=$ Bambara groundnut flour. Mean values in column bearing the identical superscripts are significantly not different $(\mathrm{P}>0.05)$ of duplicate determinations.

The whole investigation as shown in Table 6a, on the microbiological investigation generally revealed moderate counts. The extent to which a product is contaminated by microorganisms depends on the level of hygiene and sanitary status of handlers and material used in the production chain. Also the degree of humidity of a food material is responsible for the growth or inhibition of microorganisms. Low moisture foods contain no more than $25 \%$ moisture and water activity of 0.00 to 0.60 [40]. Bacteria require relatively high level of moisture for growth. This is the reason for low level of counts despite high moisture content.

Microbial findings revealed the total microbial load of $1.23 \times 10^{3} \mathrm{cfu} / \mathrm{g}$ (Table $\mathbf{6 b}$ ), showed that Salmonella and Escherichia coli were not detected in fura made from 80:20 millet-Bambara nut flour blend. Staphylococcus aureus, Staphylococcus epidemidis, Salmonella spp, Klebsiella spp, Pseudomonas and Escherichia coli were isolated with the following percentage of occurrences $32.28 \%, 25.00 \%, 3.48 \%, 16.46 \%, 19.62 \%$ and $3.16 \%$ respectively. The occurrence of such bacteria as Staphylococcus aureus and E. coli in the fura samples investigated 


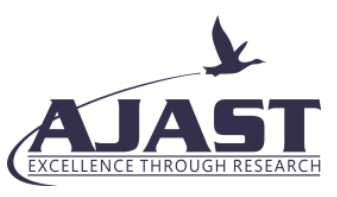

Asian Journal of Applied Science and Technology (AJAST)

Volume 5, Issue 3, Pages 13-31, July-September 2021

in this study should be of public health concerns because these two have implicated in various diseases of man [41, $42,43,44]$.The percentage occurrences of the bacteria identified in this study showed that Staphylococcus aureus recorded the highest frequency in the fura samples. Moreover, the total bacterial counts recorded from the different fura food samples did not exceed the limits for ready-to-eat foods of $10^{2}$ to $<10^{4} \mathrm{cfu} / \mathrm{g}$ prescribed by the Food Standards[45] and Centre for Food Safety[46]. The low microbial load recorded in this study is in agreement with the observations by Nester et al.[47] and Adam and Moss[48], who attributed their observations to the low water activity (aw) values of dehydrated foods which are usually below 0.6.

Table 6a. Total bacterial count of the processed Fura food samples under a 3-day room temperature

\begin{tabular}{ll}
\hline Formulation & TVC x 10 $^{3}(\mathbf{c f u} / \mathbf{g})$ \\
\hline $\mathrm{F}_{0} \mathrm{M}_{\mathrm{f}}(100: 00)$ & $1.23 \pm 0.00^{\mathrm{a}}$ \\
$\mathrm{F}_{1} \mathrm{M}_{\mathrm{f}} \mathrm{B}(90: 10)$ & $1.17 \pm 0.00^{\mathrm{b}}$ \\
$\mathrm{F}_{2} \mathrm{M}_{\mathrm{f}} \mathrm{B}(80: 20)$ & $1.09 \pm 0.00^{\mathrm{c}}$ \\
\hline
\end{tabular}

$\mathrm{F}=$ Fura Subscripts 1 and 2 denote Bambara groundnut flour levels $10 \% \& 20 \%$, Fo represents the control, $\mathrm{M}_{\mathrm{f}}=$ Millet flour, $\mathrm{B}_{\mathrm{f}}=\mathrm{Bambara}$ groundnut flour. Mean values in the column bearing the identical superscripts are significantly not different $(\mathrm{P}>0.05)$ of duplicate determinations.

$\mathrm{TVC}=$ Total viable count, $\mathrm{cfu} / \mathrm{g}=$ coliform forming unit per gram, of the food sample

Table 6b. Prevalence of bacteria related to Bambara groundnut supplemented Pearl millet-based fura and Control.

\begin{tabular}{|c|c|c|c|c|c|c|}
\hline \multirow[t]{2}{*}{ Sample code } & \multicolumn{6}{|c|}{ Bacterial isolates of the foods } \\
\hline & S. aureus & S. epidemidis & Salmonella spp & Klebsiella spp & Pseudomonas spp & E. coli \\
\hline $\mathrm{F}_{0} \mathrm{M}_{\mathrm{f}}(100: 00)$ & 28 & 34 & 7 & 26 & 24 & 7 \\
\hline $\mathrm{F}_{1} \mathrm{M}_{\mathrm{f}} \mathrm{B}(90: 10)$ & 39 & 17 & 4 & 10 & 12 & 3 \\
\hline $\mathrm{F}_{2} \mathrm{M}_{\mathrm{f}} \mathrm{B}(80: 20)$ & 35 & 28 & ND & 16 & 26 & ND \\
\hline Total & 102 & 79 & 11 & 52 & 62 & 10 \\
\hline Mean & 34.00 & 26.33 & 3.67 & 17.33 & 20.67 & 3.33 \\
\hline \multicolumn{7}{|l|}{$\%$} \\
\hline Occurrence & 32.28 & 25.00 & 3.48 & 16.46 & 19.62 & 3.16 \\
\hline
\end{tabular}

$\mathrm{F}=$ Fura Subscripts 1 and 2 denote Bambara groundnut flour levels $10 \% \& 20 \%$, Fo represents the control, $\mathrm{M}_{\mathrm{f}}=$ Millet flour, $\mathrm{B}_{\mathrm{f}}=$ Bambara groundnut flour.

Mean values in column bearing the identical superscripts are significantly not different $(P>0.05)$ of duplicate determinations. $\mathrm{ND}=$ Not determined.

Millet flour, $\mathrm{B}_{\mathrm{f}}=$ Bambara groundnut flour, $\mathbf{S} .=$ Staphyllococcus, $\mathrm{Spp}=$ Specie, E= Escherichia, ND= Not Detected, 


\section{Anti-nutrients Composition of the Flours and the Blends}

The anti-nutritional factors of the raw material flours and the blends for fura formulations are presented in Table 7a. Tannin, Alkaloid and Phytic acids contents ranged from 0.18 to $0.25 \mathrm{~g} / 100 \mathrm{~g}, 2.75$ to $3.50 \mathrm{~g} / 100 \mathrm{~g}$. and 8.93 to $13.81 \mathrm{mg} / 100 \mathrm{~g}$ respectively. All the parameters, tannin, alkaloid and phytic acids as anti-nutritional factors in this study decreased with bambara groundnut flour inclusion (0-20\%). This is as a result of the low content of anti-nutrients in the bambara groundnut and to its high concentration in the millet flour. The decrease in the tannin content might be attributed to the low content of tannin in bambara groundnut as compared to that of millets. The results obtained agreed with the report of Kulthe et al. [30] who characterized millet cultivars on the basis of some physical and chemical properties, and the report of Gull et al. [49] on Fura evaluation. Tannin binds to both exogenous and endogenous proteins including enzymes of the digestive tract affecting the utilization of proteins [50](Griffiths, 1985). Alkaloids are secondary metabolites and show strong effects on animal and human organism on very small dozes. Alkaloids are not only present in daily human life in food but also as stimulant drugs, they show anti-inflammatory, anti-cancer, analgesics etc. The phytic acids contents were lower when compared with the report of Kulthe et al.[30] on anti-nutritional contents of some pearl millet cultivars and the work of Florence and Asna[51] on influence of germination on bio-accessible iron and calcium in pearl millet. Kheterpaul and Chauhan [52] reported pearl millet with a value of $990 \mathrm{mg} / 100 \mathrm{~g}$ of phytic acid, Kumar and Chauhan [53] reported value of $825.7 \mathrm{mg} / 100 \mathrm{~g}$, while El-Hag et al. [54] reported a values of 943 and $1076 \mathrm{mg} / 100 \mathrm{~g}$ of phytic acid in two Sudanese wheat cultivars. The low phytic acid content could be due to varietal differences and also the effect of processing. Many processing techniques such as cooking, germination, soaking reduces the contents of anti-nutrients.

Table 7a. Anti-nutrients Composition of the Flours and the Blends

\begin{tabular}{llll}
\hline Formulation & Tannin $(\mathrm{g} / 100 \mathrm{~g})$ & Alkaloid $(\mathrm{g} / 100 \mathrm{~g})$ & Phytic Acid $(\mathrm{mg} / 100 \mathrm{~g})$ \\
\hline $\mathrm{M}_{\mathrm{f}}(100: 00)$ & $0.25 \pm 0.01^{\mathrm{a}}$ & $3.50 \pm 0.28^{\mathrm{a}}$ & $13.81 \pm 0.16^{\mathrm{a}}$ \\
$\mathrm{B}_{\mathrm{f}}(100: 00)$ & $0.18 \pm 0.00^{\mathrm{c}}$ & $2.75 \pm 0.07^{\mathrm{b}}$ & $8.93 \pm 0.16^{\mathrm{c}}$ \\
$\mathrm{M}_{\mathrm{f}} \mathrm{B}(90: 10)$ & $0.21 \pm 0.01^{\mathrm{b}}$ & $2.92 \pm 0.02^{\mathrm{b}}$ & $12.65 \pm 0.16^{\mathrm{b}}$ \\
$\mathrm{M}_{\mathrm{f}} \mathrm{B}(80: 20)$ & $0.20 \pm 0.01^{\mathrm{bc}}$ & $2.86 \pm 0.01^{\mathrm{b}}$ & $12.18 \pm 0.16^{\mathrm{b}}$ \\
\hline
\end{tabular}

$\mathrm{M}_{\mathrm{f}}=$ Fine millet flour $\mathrm{B}_{\mathrm{f}}=$ Bambara groundnut flour

Mean values in the column bearing the identical superscripts are significantly not different $(\mathrm{P}>0.05)$

\section{Anti-nutrients Contents of the Bambara groundnut supplemented Pearl Millet-Based Fura and Control}

The anti-nutritional contents of the bambara groundnut supplemented pearl millet-based Fura is presented in Table 7b. The concentration of alkaloids, flavonoids, phytic acids and tannins ranged from 0.09 to $0.15 \mathrm{~g} / 100 \mathrm{~g}, 0.28$ to $0.35 \mathrm{~g} / 100 \mathrm{~g}, 7.31$ to $9.83 \mathrm{~g} / 100 \mathrm{~g}$ and 0.04 to $0.16 \mathrm{~g} / 100 \mathrm{~g}$. The decrease in the anti-nutritional factors as bambara groundnut was added, was also recorded at products as was seen in the raw materials anti-nutrients analysis. Alkaloid are active components of stimulants, tranquilizers and are not only in food systems but in also in medicine because they can act quickly in specific areas of the nervous system. The results obtained in this study may be 
explained that the foods made from millet may have medicinal property. The flavonoids, phytic acid and tannins contents were similar to the report of Owheruo et al. [55] on the physicochemical properties of malted finger and pearl millet where he reported phytic acid content of pearl millet as $910 \mathrm{mg} / 100 \mathrm{~g}$, tannin content of pearl millet as $0.10 \mathrm{~g} / 100 \mathrm{~g}$. Tannin have been reported to lower digestibility of most nutrients especially protein [56]. Flavonoid has been reported to exhibit anti-oxidant activity, the presence of flavonoid in foods, a phenolic compound may contribute to health potential of the food. There was a general decrease in the anti-nutritional content of treated fura when compared with their levels in the raw materials. This might be attributed to the method of processing which the flours were subjected to; soaking, de-hulling, cooking etc. The outlined processing methods have been found to reduce anti-nutrient levels for many seeds.

Table 7b. Anti-nutrients Contents of the Bambara Groundnut Supplemented Pearl Millet-Based Fura and Control

\begin{tabular}{|c|c|c|c|c|}
\hline Sample code & Alkaloid (g/100g) & $\begin{array}{c}\text { Flavonoid } \\
\text { (g/100g) }\end{array}$ & $\begin{array}{c}\text { Phytic acid } \\
\text { (mg/100g) }\end{array}$ & Tannin $(\mathrm{g} / \mathbf{1 0 0 g})$ \\
\hline $\mathrm{F}_{0} \mathrm{M}_{\mathrm{f}}(100: 00)$ & $0.15 \pm 0.01^{\mathrm{a}}$ & $0.35 \pm 0.01^{\mathrm{a}}$ & $9.83 \pm 0.12^{\mathrm{a}}$ & $0.16 \pm 0.00^{\mathrm{a}}$ \\
\hline $\mathrm{F}_{1} \mathrm{M}_{\mathrm{f}} \mathrm{B}(90: 10)$ & $0.12 \pm 0.00^{\mathrm{b}}$ & $0.30 \pm 0.00^{\mathrm{b}}$ & $9.17 \pm 0.16^{\mathrm{a}}$ & $0.15 \pm 0.01^{\mathrm{a}}$ \\
\hline $\mathrm{F}_{2} \mathrm{M}_{\mathrm{f}} \mathrm{B}(80: 20)$ & $0.09 \pm 0.07^{\mathrm{c}}$ & $0.28 \pm 0.01^{\mathrm{c}}$ & $7.31 \pm 0.49^{\mathrm{b}}$ & $0.04 \pm 0.01^{\mathrm{b}}$ \\
\hline
\end{tabular}

$\mathrm{F}=$ Fura Subscripts 1 and 2 denote Bambara groundnut flour levels $10 \% \& 20 \%$, Fo represents the control, $\mathrm{M}_{\mathrm{f}}=$ Millet flour, $\mathrm{B}_{\mathrm{f}}=$ Bambara groundnut flour.

Mean values in the column bearing the identical superscripts are significantly not different $(P>0.05)$ of duplicate determinations.

\section{In-vitro Protein and Starch Digestibility of the Bambara Groundnut Supplemented Pearl Millet-Based Fura and the Control}

The in-vitro protein and starch digestibility of the bambara groundnut supplemented pearl millet fura and the control are presented in Table 4.8. At $1 \mathrm{hr}$ the in-vitro protein digestibility ranged from 72.67 to $75.43 \%$ with $\mathrm{F}_{2} \mathrm{M}_{\mathrm{f}} \mathrm{B}$ (80:20) being the highly digestible greater than the other food formulations and $\mathrm{F}_{0} \mathrm{M}_{\mathrm{f}}$ (100:00) being the least digestible with $72.67 \%$. At 6 hrs the same formulations $\left(\mathrm{F}_{2} \mathrm{M}_{\mathrm{f}} \mathrm{B}\right.$ (80:20) and $\mathrm{F}_{0} \mathrm{M}_{\mathrm{f}}$ (100:00) maintained being the highest and least digestible. In-vitro-starch digestibility ranged from 66.83 to $70.25 \%$ with $\mathrm{F}_{0} \mathrm{M}_{\mathrm{f}}(100: 00)$ being the highly digestible, greater than the other food formulations and $\mathrm{F}_{2} \mathrm{M}_{\mathrm{f}} \mathrm{B}$ (80:20) being the least. In-vitro protein digestibility increased with an increase in bambara groundnut grain flour inclusion (0-20\%) to the pearl millet flour. The increase in in-vitro protein digestibility at $1 \mathrm{~h} \& 6 \mathrm{~h}$ might be attributed to the bambara groundnut grain flour inclusion as it is a grain rich in protein. Mohammed et al., [57] (2018) reported that supplementation of millet flour with $15 \%$ moringa seed flour significantly $(\mathrm{p}<0.05)$ increased the in-vitro protein digestibility of the supplemented flour up to $79.42 \%$. The increment in in-vitro protein digestibility could also be due to anti-nutrients degradation by microorganisms and to partial degradation of complex storage proteins into simple and soluble products. Boiling was also found to improve in-vitro protein digestibility (Aremu et al.,[58] (2016)), they worked on the effects of 
processing on protein digestibility of underutilized grain legumes in Nigeria. The present study tallies with the report of El Hag et al.[54] and Taylor and Taylor [59], they observed that combination of fermentation and cooking significantly improved the digestibility of sorghum. The improvement of protein digestibility after boiling was due to the reduction in anti-nutritional factors such as saponins, alkaloids, tannins and cyanide. The starch digestibility decreased with an increase in the level of bambara groundnut flour inclusion into the pearl millet fura. This might be attributed to the high amylase content since high amylase content may reduce starch digestibility [60]. In general, millet protein digestibility can be reduced by several factors, most notably the presence of tannin and dietary fibre (Annor et al., [60], these foods are found to be low in dietary fibre.

Table 8. In-vitro Protein Digestibility of Bambara Groundnut Supplemented Pearl Millet-Based Foods, Controls

\begin{tabular}{llll}
\hline Sample code & $\begin{array}{l}\text { Protein Digestibility } \\
@ 1 \mathrm{hr}\end{array}$ & $\begin{array}{l}\text { Protein Digestibility } \\
@ 6 \mathrm{hrs}\end{array}$ & $\begin{array}{l}\text { Starch } \\
\text { Digestibility }\end{array}$ \\
\hline $\mathrm{F}_{0} \mathrm{M}_{\mathrm{f}}(100: 00)$ & $72.67 \pm 0.01^{\mathrm{c}}$ & $73.95 \pm 0.01^{\mathrm{c}}$ & $70.25 \pm 0.01^{\mathrm{a}}$ \\
$\mathrm{F}_{1} \mathrm{M}_{\mathrm{f}} \mathrm{B}(90: 10)$ & $73.16 \pm 0.01^{\mathrm{b}}$ & $76.45 \pm 0.01^{\mathrm{b}}$ & $68.37 \pm 0.01^{\mathrm{b}}$ \\
$\mathrm{F}_{2} \mathrm{M}_{\mathrm{f}} \mathrm{B}(80: 20)$ & $75.43 \pm 0.01^{\mathrm{a}}$ & $79.13 \pm 0.01^{\mathrm{a}}$ & $66.83 \pm 0.01^{\mathrm{c}}$
\end{tabular}

$\mathrm{F}=$ Fura Subscripts 1 and 2 denote Bambara groundnut flour levels $10 \% \& 20 \%$, Fo represents the control, $\mathrm{M}_{\mathrm{f}}=$ Millet flour, $\mathrm{B}_{\mathrm{f}}=$ Bambara groundnut flour.

Mean values in the column bearing the identical superscripts are significantly not different $(\mathrm{P}>0.05)$ of duplicate determinations.

Table 9 shows the sensory properties of the bambara groundnut supplemented millet-based fura samples. There was no significant difference $(\mathrm{p}<0.05)$ in the sensory properties of fura from 100\% millet and 90:10\% millet-bambra nut fura in appearance, aroma and general acceptability, but the fura samples varied as further level of bambara groundnut (0-20\%) was increasingly added except for the general acceptability which maintained no significant difference. Fura from 80:20 (millet-bambara bean) flour blend received best score and most preferred.

Table 9. Sensory properties of pearl millet-Bambara-groundnut first

\begin{tabular}{lllllc}
\hline Sample code & Appearance & Aroma & Texture & Mouth feel & General acceptability \\
\hline $\mathrm{F}_{0} \mathrm{M}_{\mathrm{f}}(100: 00)$ & $6.400 \pm 0.699^{\mathrm{b}}$ & $6.500 \pm 0.827^{\mathrm{a}}$ & $6.200 \pm 0.768^{\mathrm{a}}$ & $6.200 \pm 1.105^{\mathrm{a}}$ & $5.300 \pm 0.923^{\mathrm{b}}$ \\
& & & & \\
$\mathrm{F}_{1} \mathrm{M}_{\mathrm{f}} \mathrm{B}(90: 10)$ & $5.900 \pm 0.718^{\mathrm{b}}$ & $7.200 \pm 0.768^{\mathrm{a}}$ & $4.500 \pm 1.051^{\mathrm{b}}$ & $4.400 \pm 0.821^{\mathrm{b}}$ & $6.200 \pm 1.105^{\mathrm{ab}}$ \\
& & & & & \\
$\mathrm{F}_{2} \mathrm{M}_{\mathrm{f}} \mathrm{B}(80: 20)$ & $7.600 \pm 0.821^{\mathrm{a}}$ & $4.300 \pm 1.301^{\mathrm{b}}$ & $5.700 \pm 0.657^{\mathrm{a}}$ & $5.800 \pm 1.005^{\mathrm{a}}$ & $6.800 \pm 0.894^{\mathrm{a}}$ \\
\hline
\end{tabular}

$\mathrm{F}=$ Fura Subscripts 1 and 2 denote Bambara groundnut flour levels $10 \%$ \& 20\%, Fo represents the control, $\mathrm{M}_{\mathrm{f}}=$ Millet flour, $\mathrm{B}_{\mathrm{f}}=$ Bambara groundnut flour.

Mean values in the column bearing the identical superscripts are significantly not different ( $p>0.05)$ of twenty (20) respondents. 


\section{Conclusion}

In conclusion, fortification of the millet-based Fura, with Bambara groundnut flour (0-20\%) had improved the ash, fat, protein and energy contents of fura. The microbial load in the processed fura samples revealed moderate counts which mean that the foods were safe for consumption. Finally the study had succeeded in improving the functional, nutritional quality as well as sensory properties of the millet-bambara groundnut fura. The food can be considered an alternative source of protein and fat not only to inhabitants of the North-Eastern Nigeria but also to any who considers it a food item worthy for consumption. It is recommended that further studies on the modified fura should be based on formulating shelf-stable fura flour as will facilitate the acceptability of fura in other regions of the world. The amino acid profile of the processed fura needs also to be investigated in order to re-assure its nutrient-density t furs consumer.

\section{Declarations}

\section{Source of Funding}

This research did not receive any grant from funding agencies in the public, commercial, or not-for-profit sectors.

\section{Competing Interests Statement}

The authors declare no competing financial, professional and personal interests.

\section{Ethical Approval}

Ethical approval for this research was based on institutional guidelines.

\section{Consent for publication}

Authors declare that they consented for the publication of this research work.

\section{Availability of data and material}

Authors are willing to share data and material according to the relevant needs.

\section{References}

[1] Baltensperger, D. D. (1996). Foxtail and Proso Millet in: Progress in New Crops. Journal. Janick, ed. Progress in New Crops, ASHS Press, Alexandria, and V.A Pages 182-190.

[2] Obilana, A.B., and Manyasa, E. (2002). Millets. Pages 177-217 in: Pseudo Cereals and Less Common Cereals: Grain Properties and Utilization Potential. P. S. Belton, and J. R. N. Taylor, eds. Springer Verlag, New York.

[3] FAO, ICRISAT. (1996). The world Sorghum and Millet Economics. Facts Trends and Outlook. Food and Agriculture of the United Nations. Rome, Italy and International crops Research Institute for the Semi-arid Tropics. Pantacharu 502324, Andira, India.

[4] Nkama, I., and Ikwelle, M.C. (1997). Assessment of Food Quality of Millet Grain. Pearl Millet in Nigerian Agriculture, Production, Utilization and Research Priorities. Proceeding of the Pre-season National Coordinated Research Program on Pearl Millet, Maiduguri held on April 1997. 
[5] Jideani, VA. (1999) Traditional and possible Technology uses of Digitaria exillis (Acha) and Digitaria ibrua. Review Plant Foods Human Nutrition; 54:362-373.

[6] Jideani, V.A, Nkama, I., and Agbo, E.D. (2001). Survey of Fura production in some North-Eastern States of Nigeria. Plant Food Human Nutrition; 56:23-26.

[7] Goli, A.E. (1997). Bambara Groundnut ( Vigna subterranean (L) Verdc.). In: Heller J, Begemann F, Mushonda J (eds) Promoting the Conservation and use of Underutilized and Neglected Crops, vol 9. International Plant Genetic Resources Institute, Rome, p 167.

[8] Mkandawire CH (2007). Review of Bambara groundnut production. Sub-Saharan Africa, J. of Agri. 2:464-470. [9] Malik, H., Gulzar, A.N., and Dar, B.N. (2015) Optimisation of Process for Development of Nutritionally Enriched Multigrain Bread. Journal of Food Process Technology, 7:544.

[10] Adu-Dapaah, H.K., and R.S. Sangwan, (2004). Improving Bambara Groundnut Productivity using gamma Irradiation and in-vitro techniques. African Journal of Biotechnology, 3: 260-265.

[11] Yagoub, A.E.G.A., and Abdalla, A.A. (2007). Effect of Domestic Processing Methods on Chemical Composition, In-vitro Digestibility of Protein and Starch and Functional Properties of Bambara Groundnut (Vigna subterranea) Seed. Research. Journal of Agricultural Biology.

[12] Nkama I. (1993). Studies on Improving the Nutritional Quality of Masa-a Traditional Nigerian Fermented Cereal Based Food. A report to the United Nations University. Mysore, India: Central Food Technology Research Institute (CFTRI), 1-28.

[13] Onwuka, G. I. (2005). Food Analysis and Instrumentation: Theory and Practice. Naphathali Prints, NG 95-96. [14] AOAC (1990). Official Methods of Analysis (15th edition). Arlington, VA: Asso. of Off. Anal. Chem. 1:725. [15] Chinma, C.E., and Gernah, D.I. (2007). Physicochemical and Sensory Properties of Cookies Produced from Cassava/Soybean/Mango Composite Flour. Journal of Food Technology 5(3) pp. 256-260.

[16] APHA. (1992), Compendium of Methods for Microbiological Examination of Foods 3rd Edition, American Public Health Association.

[17] Ihekoronye, A.I., Ngoddy, P.O. (1985). Integrated Food Science and Technology for the Tropics. Macmillan Publisher Ltd. London; 288-289.

[18] Gomez, K.A., Gomez, A.H. (1984). Statistical Procedures for Agricultural Research, Second Edition. Wiley and sons Inc., New York USA p.68.

[19] Plaami, S.P. (1997). Content of Dietary Fibre in Foods and its Physiological Effects, Food Rev. Int. 13:27-76. [20] James, S., Akosu N.I., Maina, Y.C., Baba, A.I., Nwokocha, L., Amuga S.J., Yohanna, A., and Maxwell, Omeiza., Y.M. (2018) Effect of Addition of Processed Bambara Groundnut on the Functional and Sensory Acceptability of Millet-Based Infant Formula. Food Science Nutrition. June; 6(4): 783-790. 
Asian Journal of Applied Science and Technology (AJAST)

Volume 5, Issue 3, Pages 13-31, July-September 2021

[21] Adebayo-Oyetoro, A.O and Shotunde, A.B. and Adeyeye Samuel, A.O. and Ogundipe, O.O. (2017). Quality

Evaluation of Millet-Based Fura Powder Supplemented with Bambara Groundnut. International Journal of Food Science, Nutrition and Dietetics (IJFS), 6 (3). pp. 358-362.

[22] Karuna, D., Noel, G., and Dilip, K. (1996). Food and Nutrition Bulletin. United Nation Univ., 17(2), 252-253.

[23] Agbara, G. I., Masaya, F. A., Badau, M. H., Igwegbe, O. A., \& Yakaka, A. M. (2018) Evaluation of Functional, Proximate, Microbial and Sensory Properties of Pearl Millet-Bambara Groundnut Yartsala (A Traditional Deep-Fried Fermented Puff), Asian Journal of Agriculture and Food Sciences: Vol. 6 No. 2.

[24] Ruth, S., Johanna, N., Disorn, S., Tobias, N., Mirja, E.G., Lena, R., Christopher, L.S., Stackelberg, O.V., Johnson, T., Nabers, D., Romy, K., Kratz, M., and Hans-Ulrich, K., Cornelia, M.U., Rudolf, K.T. (2018) Effects of Intermittent and Continuous Calorie Restriction on Body Weight and Metabolism over 50 wk: a Randomized Controlled Trial. The American J. of Clinical Nutrition, Volume 108, Issue 5, November 2018, Pages 933-945.

[25] Olaleye, A., Adeyeye, E., and Adesina, A. (2013). Chemical Composition of Bambara Groundnut (Vigna. subterranea L. Verdc). Seed parts. Bangladesh Journal of Scientific and Industrial Research, 48(3), 167-178.

[26] Alison M. Stephen, Martine-J Champ, Susan J. Cloran, Mathilde Fleith, Lilou Van Lieshout, Heddie Mejborn, Victoria J. Burley (2017). Dietary fibre in Europe: Current state of knowledge on definitions, sources, recommendations, intakes and relationships health. Nutritional Research. Review, 30 (2): 149-190.

[27] Igbabul, B., Adole, D., and Sule, S. (2013). Proximate Composition, Functional and Sensory Properties of Bambara groundnut (Voandzeia subterranean), Cassava (Manihot Esculentus) and Soybean (Glycine Max) Flour Blends for "Akpekpa" Production. Current Research Nutrition Food Science; 1(2).

[28] Amarteifio, J.O., Tibe, O., and Njogu, R.M. (2006): "The Mineral Composition of Bambara Groundnut (Vigna subterranea (L) Verdc) grown in Southern Africa." African Journal of Biotechnology 5, no.23 2408-2411.

[29] Léder, I. (2004). Sorghum and Millets, In: Cultivated Plants, Primarily as Food Sources, [Ed. György Füleky], in Encyclopedia of Life Support Systems (EOLSS), Developed under the Auspices of the UNESCO, Eolss Publishers, Oxford, UK. pp. 1-12.

[30] Kulthe, A.A., Thorat, S.S., and Lande, S.B. (2016). Characterization of Pearl Millet Cultivars for Proximate Composition, Minerals and Anti-nutritional Contents. Advances in Life Sciences 5(11), 4672-4675.

[31] Roth, A.R., and Townsend, C.E. (2003). Nutrition and Diet Therapy 8th edn. Delmar Learning, Thomson Learning Inc. Canada. Pp 132 and cover page.

[32] Rolfes, S.R., Pinna, K., and Whitney, E. (2009). Understanding normal and Clinical Nutrition (8th Edition). [33] NHS Direct online, (2017); HTTP:England .NHS.UK/Participation.

[34] FAO, (2002). Food and Agriculture Organization/World Health Organization Expert Consultation. Magnesium. In: Human Vitamin and Mineral Requirements. Rome and Geneva: Food and Agriculture Organization of the United Nations and World Health Organization. 
Asian Journal of Applied Science and Technology (AJAST)

Volume 5, Issue 3, Pages 13-31, July-September 2021

[35] Nkama, I., and Malleshi, N.G. (1998). Production and Evaluation of Sorghum and Pearl Millet Tech., Nutritional Quality of Traditional Masa form mixture of Manual No. 2 International Crop Institute for Semi Rice, Pearl Millet, Cowpea and Groundnut. Food Nutition Arid Crops (ICRISAT). Bull., 19: 336373.

[36] Hillocks, R.J., Bennett, C.,and Mponda, O.M. (2012). Bambara Groundnut: A Review of Utilization, Market Potential and Crop Improvement. African Crop Science Journal 20(1):1-16.

[37] Fasoyiro, S.B, Ajibade, S.R., Omole, A.J., Adeniyan, O.N., and Farinde, E.O. (2006). Proximate,Minerals and Anti-nutritional factors of some Underutilized Grain Legumes in South-Western Nigeria. Nut. Food Sci. 36:18-23.

[38] Ayo, J.A., and Aba, F. (2020). Effect of Bambara Groundnut Flour Addition on Proximate, Mineral Composition and Sensory Quality of Millet-Based Madidi: A Nigerian Solid Gel Food. Asian J. of Food Sci. 6: 1-8. [39] Chausmer, A.B., (1998) Zinc, Insulin and Diabetes. Journal of the American College of Nutrition Vol. 17(2) $109-115$.

[40] Jones, M. J.; Tanya, V. N.; Mbofung, C. M.F.; Fonkem, D. N.; \& Silverside D.E., (2001). A Microbiological and Nutritional Evaluation of the West African Dried Meat Product, Kilishi Journal of Food Technology in Africa, 6, 126-129. ISSN: 1028-6098.

[41] Gilbert U, Harrison A. (2001). Occurrence of enterotoxin producing Staphylococcus aureus in meat market in Nigeria. Journal of Food Infection. 56: 25-35.

[42] Reiman HP, Cliver DO. (Eds.) (2006). Foodborne Infections Int. Research J. Pub. Environ. Health 126.

[43] Ogbonna IO, Danladi, MS, Akinmusire O, Odu CE. (2012).Microbiological Safety and Proximate Composition of Suya stored at Ambient Temperature for six hours from Maiduguri, Northern Nigeria. Internet Journal of Food Safety. 14: 11 -16.

[44] Falegan CR, Akoja SO, Oyarekua MA. (2017). Microbiological Assessment of Suya in Ado Ekiti Metropolis, Ekiti State, Nigeria. MOJ Biol. Med. 2(3): 266-269.

[45] Food Standards, Australia New Zealand (2002). Food Standards Code, Vol.2. Canberra: Info. Australia.

[46] Center for Food Safety, (2007). Microbiological Guidelines for Ready-to-eat Foods. Centre for Food Safety and Environmental Hygiene Department, 66 Queensway, Hong Kong.

[47] Nester EW, Aderson, DG, Roberts CE, Pearsall NN, Nester MT. (2001).Microbiology, A Human perspective, (3rd Edn), McGraw Hill Company, USA. pp. 809-822.18.

[48] Adam MR, Moss MO. (2007). Food Microbiology. New Age Int. Publishers, New Delhi, India.

[49] Gull, A., Prasad, K., and Kumar., P. (2015). Effect of Millet Flours and Carrot Pomace on Cooking Qualities, Colour and Texture of Developed Pasta. Food Science and Technology, 63, 470-474.

[50] Griffths, D.W. (1985). The Inhibition of Digestive Enzymes by Polyphenolic Compounds. Exp. Biologically. Mediated. 199: 504-516. 
[51] Florence, S.P., Asna, U., Asha, M. R., and Jyotsna, R. (2014). Sensory, Physical and Nutritional Qualities of Cookies Prepared from Pearl Millet (Pennisetum typhoideum). J. of Food Processing and Technology.5(10):377.

[52] Kheterpaul, N., and Chauhan, B. M. (1991). Effect of Natural Fermentation on Phytate and Polyphenolic Content and in-vitro Digestibility of Starch and Protein of Pearl Fillet (P. typhodeum). J. of Sci., Food \& Agri. 55.

[53] Kumar, A., and Chauhan, B. M. (1993). Effects of phytic acid on protein digestibility (in vitro) and HCl-Extractability of Minerals in Pearl Millet sprouts. Cereal Chemistry.70: 504-506.

[54] El-Hag, M. E., El-Tinay, A. H. and Yousif, N. E.(2002). Effect of fermentation and De-hulling on Starch, total Polyphenols, Phytic Acid Content and in-vitro Protein Digestibility of Pearl Millet. Food Chemistry.77: 193-196. [55] Owheruo, J.O., Ifesan, B.O.T., and Kolawole, A.O. (2018). Physicochemical Properties of Malted Finger (Eleusine corocana) and Pearl Millet (Pennisetum glaucum). Journal of Food Science and Nutrition: 7:476-482.

[56] Ali, M.A.M., Tinay, A.H., and Abdalla, A.H. (2003). Effect of Fermentation on the in-vitro Protein Digestibility of Pearl Millet. Food Chemistry 80(1) 51-4.

[57] Mohammed Nour, A. A., Mohamed, A. R., Adiamo, O. Q., \& Babiker, E. E. (2018). Changes in Protein Nutritional Quality as affected by Processing of Millet Supplemented with Moringa Seed Flour. Journal of the Saudi Society of Agricultural Sciences, 17(3), 275-281.

[58] Aremu, M.O., Ibrahim, H., Ekanem, B., (2016). Effect of Processing on In-vitro Protein Digestibility and Anti-Nutritional Properties of three under-utilized Legumes Grown in Nigeria. BBJ/2258.

[59] Taylor, J., and Taylor, J.R.N. (2002). Alleviation of the Adverse Effects of Cooking on Protein Digestibility in Sorghum through Fermentation in Traditional African Porridges. Int. J. of Food Sci. and Technology. 37, 129-138. [60] Annor, G.A., Tyl, C., Marcone, M., Ragee, S., and Marti, A. (2017). Why do Millets have lower Starch and Protein Digestibility than other Cereals? Trends in Food Science and Technology, Vol. 66, no. supplement c, pp. 78-83. 